\title{
3P, un ,virus” reactivat, care amenință sănătatea justiției penale
}

\author{
Prof. univ. dr. Valerian Cioclei \\ Facultatea de Drept, Universitatea din București \\ Avocat, partener of counsel ZRVP
}

Rezumat: Politica penală populistă ( pe scurt 3 P), acesta este „virusul” supus prezentei analize. Există unele ,semne clinice” care sugerează că ne aflăm intr-o perioadă de reactivare a acestui virus. Aceasta este ipoteza care trebuie verificată. Ca atare, în buna tradiție metodologică medicală (căci vorbim despre un virus) se impune, mai întâi, o scurtă ,,anamneză epidemiologică " (I), după care, o evaluare a ,stării patologice actuale” (II).

Cuvinte cheie: inflație legislativă, escaladarea pedepselor, banalizarea justiției penale, infracțiuni contra libertății sexuale, viol, act sexual cu un minor, detenție pe viață.

\section{P, a reactivated "virus" which threatens the health of the criminal justice}

Abstract: Populist penal policy (in short 3P), this is the "virus" subject to this analysis. There are some "clinical signs" that suggest that we are in a period of reactivation of this virus. This is the hypothesis that needs to be verified. As such, in the good medical methodological tradition (because we are talking about a virus) it is necessary, firstly, a short "epidemiological anamnesis" (I), after which, an evaluation of the "current pathological condition" (II).

Key words: legislative inflation, escalation of punishments, trivialization of criminal justice, crimes against sexual freedom, rape, sexual intercourse with a minor, life imprisonment.

Politica penală populistă ( pe scurt 3 P), acesta este virusul la care mă refer. El bântuie de multă vreme prin societatea noastră. Ca orice virus care se respectă, a avut episoade de „epidemie” care au alternat cu stări de acalmie. În prezent, sunt unele ,semne clinice” care sugerează că ne aflăm într-o perioadă de reactivare a acestui virus. Aceasta este ipoteza care trebuie verificată. Ca atare, în buna tradiție metodologică medicală (căci vorbim despre un virus) se impune, mai întâi, o scurtă ,anamneză epidemiologică” (I), după care, o evaluare a ,stării patologice actuale" (II). 


\section{I. „Anamneza epidemiologică”}

Exacerbarea sentimentului de insecuritate publică, prin toate mijloacele, cu precădere a celor de informare în masă, urmată de propunerea și adoptarea unor soluții „salvatoare”, precum introducerea de noi incriminări sau sporirea pedepselor, în scopul de a obține voturi sau de a „fideliza” electoratul. Aceasta este, în opinia mea, definiția politicii penale populiste, un ,truc" aducător de voturi folosit de multă vreme în democrații mai „bătrâne” ca a noastră. Apariția virusului 3P, pe meleagurile mioritice, poate fi identificată în primii ani de după 1989, perioadă ce coincide (pentru cine crede în coincidențe) cu primii ani de revenire la democrație, la alegeri libere și la promisiuni electorale. Am încercat să fiu un observator atent al politicii penale autohtone în ultimele trei decenii, astfel încât pot folosi propriile „fișe clinice" pentru o scurtă incursiune în istoricul „bolii”.

În acord cu definiția enunţată mai sus, pot fi identificate două simptome care însoțesc, de regulă, 3P: tendința excesivă spre incriminare (inflația legislativă) și tendința excesivă de sporire a sancțiunilor (escaladarea pedepselor). Am atras atenția asupra acestor două simptome, la aproximativ zece ani de la schimbarea regimului politic de la noi, când, după acumulări succesive, virusul căpăta accente epidemice, într-un articol în care vorbeam despre o criză de echilibru a justiției penale. $\mathrm{Cu}$ privire la primul simptom notam atunci următoarele: „Super-inflația în materie penală, manifestată în toate variantele arătate anterior, reprezintă în dreptul nostru o realitate ce nu mai trebuie probată. Este de amintit, totuşi, un ,record" în acest sens, respectiv publicarea intr-o singură săptămânăa în Monitorul Oficial, a două acte normative vizând modificarea și completarea Codului penal: Legea nr. 197/2000 pentru modificarea și completarea unor dispoziții din Codul penal, publicată în Monitorul Oficial nr. 568 din 15 noiembrie 2000 și Ordonanța de urgență nr. 207/2000 privind modificarea și completarea Codului penal și Codului de procedură penală, publicată în Monitorul Oficial nr. 594 din 22 noiembrie 2000. Ambele acte normative au avut însă un destin meteoric, cel puțin în privința unora dintre modificările aduse. Astfel legea nr. 197/2000 care modificase substanţial unele infracțiuni privitoare la viața sexuală a fost ,amendată" din acest punct de vedere prin apariția O.U.G. nr. 89/21.06.2001. La rândul ei O.U.G. nr. 207/2000 a suferit modificări și completări odată cu adoptarea Legii nr. 456/18.07.2001 (lege pentru aprobarea O.U.G. nr. 207/2000). Aceste „modificări ale modificărilor” sunt atât de relevante în privința nivelului inflației penale, încât fac inutil orice comentariu..."1. În legătură cu cel de al doilea simptom am arătat următoarele: „Înăsprirea regimului sancționator se poate realiza, în principal, prin trei modalităţi: majorarea limitelor generale ale pedepselor, majorarea limitelor speciale ale pedepselor pentru unele infracțiuni și incriminarea unor noi variante

\footnotetext{
${ }^{1}$ V. Cioclei, Despre nevoia de echilibru în justiția penală, Analele Universității București seria Drept, 2001 sau , Critica rațiunii penale. Studii de criminologie juridică și drept penal, Ed. C.H. Beck, 2009, p. 6.
} 
agravante sau calificate ale unor infracțiuni. Toate aceste trei modalități se regăsesc în Legea nr. 140/1996, care reprezintă o primă cotă de referință a tendinței de sporire a pedepselor manifestată după anul 1990 (...). Preocuparea pentru sporirea pedepselor a continuat și ulterior intrării în vigoare a Legii nr. 140/1996, un ultim exemplu semnificativ din acest punct de vedere fiind reprezentat de Ordonanța de urgență nr. 207/2000, aprobată cu modificări și completări prin Legea nr. 456/2001 despre care am mai amintit"'. După ce am explicat ineficiența unor astfel de măsuri și „pagubele colaterale” pe care le produc am concluzionat că: ,....atât inflația legislativă cât și escaladarea pedepselor produc efecte perverse (contrare așteptărilor), au un caracter nociv. Aceste tendințe trebuie estompate. Ar fi un prim pas al justiției penale, spre regăsirea echilibrului pierdut"”.

După o scurtă perioadă de acalmie, situația a început din nou să se înrăutățească, astfel încât, după aproximativ încă un deceniu, virusul a căpătat din nou accente epidemice. Mutațiile apărute în „structura genetică a virusului” au adus o nouă simptomatologie, mai gravă, banalizarea justiției penale. Practic, acest nou simptom cuprindea, ca un ,produs doi în unul”, ambele simptome detectate cu un deceniu în urmă: inflația legislativă și escaladarea pedepselor. În „fișa clinică” întocmită la vremea respectivă am arătat că banalizarea justiției penale „s-ar traduce printr-o alunecare în derizoriu, în neserios, a tot ceea ce este legat de justiția penală, de la elaborarea legii și până la aplicarea sau respectarea ei (...) Cel mai important vector al banalizării ideii de justiție penală își are originea în chiar sfera politicii penale a ultimelor două decenii, o politică haotică, inflaționistă și superficială în plan legislativ. Acest tip de politică a generat o situație inedită, respectiv faptul că ne raportăm la trei Coduri penale, unul în vigoare, altul prorogat și altul aflat în fază de proiect. Această stranie situație nici nu ar trebui să ne preocupe prea mult, dacă nu ar fi completată de invazia incriminărilor din legile speciale. În acest segment al materiei penale lucrurile sunt realmente scăpate de sub orice control. Din acest punct de vedere se poate vorbi despre banalizarea prin penalizare. Într-o dezlănțuire kafkiană, legiuitorul ultimilor ani a penalizat, în aproape fiecare domeniu de activitate, modalități specifice de furturi, înșelăciuni, distrugeri și chiar omoruri, pe care, de regulă, lea sancționat mai aspru, ca variante agravate ale infracțiunilor de bază. În efortul de a întocmi o evidență cât de cât actuală, Consiliul Legislativ a redactat recent o listă ce cuprinde 250 de legi penale speciale sau legi extra penale ce conțin dispoziții penale. $\mathrm{O}$ astfel de evidență este însă relativă, datorită faptului că procesul de incriminare/dezincriminare sau modificare este unul permanent, iar formulele prin care se dispun abrogările implicite ale unor texte sunt vagi și discutabile. Ceea ce deranjează la aceste incriminări din legile speciale nu este doar numărul mare și lipsa unei evidențe clare, ci și tehnica legislativă, pe baza

\footnotetext{
${ }^{2}$ Idem p. 10.

${ }^{3}$ Idem p. 13.
} 
căreia sunt construite, de cele mai multe ori lamentabilă"4. $\mathrm{Cu}$ aceeași ocazie, după analiza noii simptomatologii a virusului, am propus și o ,schemă e tratament” în trei trepte: „Legislația trebuie să fie curățată, în cel mai scurt timp, de toate acele incriminări defectuoase, care parazitează justiţia penală, o împing în derizoriu, conducând la banalizarea ei. Trei pași trebuie urmaţi pentru aceasta: trebuie stopată imediat incriminarea ,,pe colțul mesei', ce are la bază propuneri, altminteri poate bine intenționate, venite de la specialiști din diverse domenii, dar care nu au nicio legătură cu dreptul penal; trebuie selectate și introduse în codul penal toate acele fapte incriminate în legi speciale, care merită în mod real o sancțiune penală, iar în aceste cazuri, textul incriminator trebuie conceput în mod inteligent; trebuie abrogate toate infracțiunile din legile speciale care, fie sunt prost concepute, fie dublează incriminările din cod, fie, pur și simplu nu merită un statut penal, putând foarte bine să rămână în sfera contravențională"s.

Într-o oarecare măsură, tratamentul prescris a fost aplicat: pentru un timp a fost oprită ,hemoragia incriminatorie”, iar prin adoptarea noului Cod penal (Legea nr. 286/20096) și, ulterior, prin Legea nr. 187/2012 pentru punerea în aplicare a Legii nr. 286/2009 privind Codul penal ${ }^{7}$ a fost restabilit echilibrul pedepselor și s-a procedat la o „dezinfecție” în zona infracțiunilor din legile speciale. Am salutat la vremea respectivă „reașezarea în limite normale a tratamentului sancționator” pe care o aducea noul proiect de $\mathrm{Cod}_{\text {penal }}{ }^{8}$. A urmat o perioadă de acalmie, care a continuat, o vreme, și după intrarea în vigoare a noului Cod penal, la 1 februarie 2014.

\section{II. „Starea patologică actuală”}

După cum a rezultat și din scurta anamneză efectuată anterior, ciclul epidemic se întinde pe o durată de aproximativ un deceniu. Dacă avem în vedere că ultima perioadă de acalmie s-a făcut simțită după adoptarea noului Cod penal în anul 2009 (cum arătam mai sus), și dacă se păstrează „modelul matematic”, este exact „momentul propice” pentru un nou „episod epidemic”.

Primele semne de reactivare a virusului au apărut, totuși, cu ceva timp în urmă. Un bun exemplu în acest sens a fost OUG nr. 18/2016. Una dintre „creațiile” acesteia a fost introducerea în Codul penal a art. 256 ${ }^{1}$ (Faptele care au

\footnotetext{
${ }^{4}$ V. Cioclei, Banalizarea justiției penale (I), Curierul judiciar nr. 10/2008 sau, Critica rațiunii penale... op.cit. p. 38.

${ }^{5}$ V. Cioclei, Banalizarea justiției penale (II), Curierul judiciar nr. 11/2008 sau, Critica rațiunii penale... op.cit. p. 47.

${ }^{6}$ M. Of. nr. 510 din 24 iulie 2009

${ }^{7}$ M. Of. nr. 757 din 12 noiembrie 2012.

${ }^{8}$ A se vedea în acest sens, V. Cioclei, Aspecte privind logica pedepselor în noul proiect de Cod penal, în Critica rațiunii penale... op.cit. p. 56 și urm.
} 
produs consecințe deosebit de grave) cu următorul conținut: „. Dacă faptele prevăzute la art. 228, 229, 233, 234, 235, 239, 242, 244, 245, 247, art. 249-251 au produs consecințe deosebit de grave, limitele speciale ale pedepsei prevăzute de lege se majorează cu jumătate". Am criticat această iniţiativă, la vremea respectivă, arătând următoarele: „Această dispoziție „,ucide” întreaga filozofie din noul Cod penal, prin care s-a încercat readucerea pedepselor la un nivel rezonabil și restabilirea unei ierarhii firești a pedepselor, ținând cont de valorile ocrotite. Am obosit să scriu despre necesitatea unui echilibru în politica penală, despre logica pedepselor în noul Cod penal, despre imensa stupizenie de a avea aceleași limite de pedeapsă pentru omor și furt calificat ${ }^{9}$ ". O altă inițiativă a Ordonanței amintite a fost aceea de a modifica diferite infracțiuni contra libertăţii și integrității sexuale în scopul declarat de a oferi o protecție sporită minorilor. Despre erorile acestor modificări, în special despre cele intervenite la infracțiunea prevăzută de art. $220 \mathrm{Cod}$ penal (Actul sexual cu un minor), am scris la momentul respectiv ${ }^{10}$. Exemplul acestei Ordonanțe este edificator pentru simptomatologia 3 P. Traduse în slogan electoral, modificările aduse prin Ordonanță ar suna în felul următor: „Noi te apărăm față de cei care te fură și cei care îți agresează sexual copiii". Cum să nu te lași sedus de un asemenea mesaj?

Pentru a completa „tabloul clinic” să trecem la ce se întâmplă ,în zilele noastre". Intrigat de o știre apărută în media, potrivit căreia violul „,se va pedepsi de acum înainte cu închisoarea pe viață" am intrat pe portalul Camerei Deputaților, pentru a vedea ce ne mai pregătesc aleșii noștri în materie de 3P. Am constatat că există două proiecte de lege care ne pot interesa în contextul prezentei analize; ambele figurează ca fiind trimise pentru raport la comisiile permanente ale Camerei Deputaților.

Primul este PL-X nr. 101/09.03.2020 - Proiect de Lege pentru modificarea și completarea Legii nr.286/2009 privind Codul penal, precum și pentru modificarea art.223 alin.(2) din Legea nr.135/2010 privind Codul de procedură penală ${ }^{11}$ (în continuare Proiectul). În mare, Proiectul reia tema protecției sexuale a minorilor, ce a constituit și obiectivul OUG nr. 18/2016, după cum am văzut mai sus. Practic, se urmărește o nouă mărire a limitelor de pedeapsă, pentru aceleași infracțiuni ale căror limite fuseseră deja mărite prin amintita Ordonanță.

Analfabetismul juridic al Proiectului răzbate din chiar expunerea de motive din care citez: „Prin urmare, considerăm necesară modificarea actelor legislative care prevăd pedepsirea infracțiunilor contra libertății și integrității sexuale a minorilor, astfel încât orice faptă care implică contact sexual cu un minor cu vârstă

\footnotetext{
${ }^{9}$ V. Cioclei, Politica penală - ,musafirul de-o prună, sau de două’?, disponibil la https://www.juridice.ro/454810/politica-penala-musafirul-de-o-pruna-sau-dedoua.html?fbclid=IwAR2kwhUfFEjsN-VnfTdChPWB1nviblbr9LUpujkmnCgFcmgmHQDXchiEfYg

${ }^{10}$ V. Cioclei, Din nou despre modificările Codului penal prin O.U.G. nr. 18/2016 sau „Mircea, fă-te că legiferezi (în penal)" disponibil la: https://www.juridice.ro/476873/din-nou-despre-modificarile-codului-penal-prin-o-u-gnr-182016-sau-mircea-fa-te-ca-legiferezi-inpenal.html?fbclid=IwAR1yx1AyAGXBygAugpsiOaVWYJLVUKqL2zNxJR-6TgJ7Hb2NMZZqWk3JaYQ

${ }^{11}$ Disponibil la: http://www.cdep.ro/pls/proiecte/upl pck2015.proiect?cam=2\&idp=18409
} 
mai mică de 15 ani să fie în mod direct încadrată ca viol, fără a fi nevoie de dovezi care să ateste imposibilitatea victimei de a se apăra sau tentativa de a opune rezistență (...). Totodată, diferența de vârstă pentru care infracțiunile nu vor fi sancționate va scădea de la 3 la 2 ani, cu scopul de a limita situațiile în care abuzatorul primește pedeapsa minimă. De asemenea, propunerea prevede creșterea vârstei minime pentru care este un astfel de act poate fi considerat consimțământ, de la 15 la 16 ani”"12 (sublinierile îmi aparțin, nu și erorile din text).

Las deoparte faptul că ,actele legislative” nu pot să prevadă ,,pedepsirea infracțiunilor”, deoarece infracțiunea este „fapta prevăzută și pedepsită de legea penală" deci, ar însemna că pedepsim pedepsele... Las deoparte și faptul că diferența de vârstă nu are nicio legătură cu ,pedeapsa minimă” primită de „abuzator” deoarece, conform art. 220 alin. (5): „faptele prevăzute în alin. (1) și (2) nu se sancționează dacă diferența de vârstă nu depășește 3 ani” (s.n.).

Nu pot trece însă cu vederea, ideea „năstrușnică” potrivit căreia „orice faptă care implică contact sexual cu un minor cu vârstă mai mică de 15 ani să fie în mod direct încadrată ca viol". În primul rând, sintagma contact sexual nu este folosită de legiuitor, nicăieri, în capitolul destinat infracțiunilor contra libertății și integrităţii sexuale. Elementul material al violului, identic cu cel al actului sexual cu un minor (ceea ce diferențiază cele două infracțiuni fiind folosirea sau nu a constrângerii în sens larg) este foarte clar prevăzut de legiuitor și el nu se referă la contact sexual. Or, chiar și un student de anul II trebuie să știe că, fără existența elementului material, infracțiunea nu poate să existe. Prin urmare, contactul sexual cu un minor nu poate fi ,încadrat direct la viol”, sub nicio formă, cel puțin în redactarea actuală a Codului penal, dar și a Proiectului discutat (care nu modifică elementul material al violului sau al actului sexual cu un minor). Cel mult, contactul sexual cu un minor ar putea intra în categoria ,act de natură sexuală" la care se referă art. 221 Cod penal (coruperea sexuală a minorilor). Dar, pentru ca această și mai mare „năstrușnicie” să producă efecte ar fi fost necesară modificarea în acest sens a art. 221 C.pen., ceea ce nu se reflectă în textul propus de Proiect. Dar, să las deoparte ,răutăţile” și să traduc eu ce au vrut să spună redactorii Expunerii de motive, dar nu au putut „cu vorbele lor”: fapta de act sexual cu un minor să fie asimilată de legiuitor cu infracțiunea de viol, în situațiile în care victima are o vârstă mai mică de 15 ani. În acest caz am fi tentaţi să spunem „toate bune și frumoase” numai că, (foarte) puțin mai departe, „modificarea propusă se modifică” și suntem anunțați că ,propunerea prevede creșterea vârstei minime pentru care este un astfel de act poate fi considerat consimțământ, de la 15 la 16 ani”. Las deoparte că „este un este” în plus în propoziție și presupun (sau intuiesc mai degrabă) că actul care poate fi „,considerat consimțământ” (corect ar fi consimțit, în opinia mea) se referă la elementul material specific actului sexual cu un minor. Or, în acest caz, propunerea ar fi ca fapta de act sexual cu un minor să fie prevăzută de legiuitor drept viol, în situațiile în care victima are o vârstă mai

\footnotetext{
${ }^{12}$ Disponibil la: http://www.cdep.ro/proiecte/2020/100/00/1/em131.pdf
} 
mică de 16 ani (nu de 15 cum se propunea cu doar câteva rânduri mai înainte). Care este până la urmă pragul? Vorba lui Farfuridi: „Din această dilemă nu puteți ieși...Am zis!”. Noroc cu Proiectul în sine care, în ciuda intenției, nu aduce nicio modificare de natură a implementa măsura proclamată, într-o formă sau alta. Această situație (ciudată și jenantă în același timp) a fost sesizată și de Consiliul Legislativ care a avizat favorabil propunerea legislativă (!?!) cu mai multe observații și propuneri printre care și următoarea: „Semnalăm că intervențiile legislative preconizate nu au ca efect, așa cum se precizează în expunerea de motive ca „orice faptă care implică contact sexual cu un minor cu vârstă mai mică de 15 ani să fie în mod direct încadrată ca viol, fără a fi nevoie de dovezi care să ateste imposibilitatea victimei de a se apăra sau tentativa de a opune rezistență". ${ }^{13}$ Cu alte cuvinte, adaptând zicala ,a uitat de la mână până la gură”, am putea spune că aleșii noștri (propunători de legi) au uitat „de la expunere până la propunere”. Nu voi face o analiză integrală a Proiectului care, cel puțin la o primă lectură, pare să conțină numeroase erori, deoarece sper că el va fi respins, pur și simplu, în Camera Deputaţilor, forul decizional. Semnalez, spre exemplificare, doar două anomalii, ce apar în forma actuală a Proiectului. Prima constă în pedeapsa prevăzută pentru o nouă variantă agravată (alin. $3^{1}$ ), introdusă la art. 213 C.pen. (Proxenetismul). Conform acestei variante, pentru faptele de proxenetism săvârșite față de un minor, în anumite ipoteze ${ }^{14}$, limita maximă a pedepsei (rezultată prin aplicarea fracțiilor de majorare propuse) ar fi de 18 ani, 7 luni și 15 zile. Dincolo de faptul că această limită se apropie ,periculos de mult” de maximul prevăzut pentru omor (20 de ani), observăm că ea depășește limita maximă de la violul comis asupra minorului, într-o variantă agravată nou introdusă prin Proiect, respectiv 15 ani ( art. 218 alin. $3^{1}$ ) și, mai mult, depășește limita maximă a pedepsei pentru violul urmat de moartea victimei, inclusiv când aceasta este un minor, limită ce este de 18 ani. Dacă vă întrebați ce logică stă la baza stabilirii acestor pedepse vă răspund eu: niciuna. Este clasica eroare a necorelării textelor, care intervine atunci când modificările unor infracțiuni se realizează fără un suport profesionist. A doua anomalie constă în ridicarea de la 15 la 16 ani a vârstei de la care o persoană ,are dreptul să întrețină acte sexuale", fără riscul de a-și trimite partenerul la „pușcărie”. Astfel, conform art. 220 alin. (4), raportat la art. 220 alin. (1) C.pen., în varianta Proiectului, dacă în ziua în care a împlinit 18 ani o persoană (indiferent de sex) întreține un act sexual cu o altă persoană (indiferent de sex) care, mai avea o zi până să împlinească 16 ani, prima persoană riscă până la 10 ani de închisoare. Nu are relevanță că persoanele respective sunt într-o relaţie de prietenie sau că, eventual, sunt îndrăgostite una de alta...În plus, este de remarcat că, în conformitate cu dispozițiile Codului civil, la împlinirea vârstei de 16 ani, în anumite condiții, o persoană se poate căsători, dar, în conformitate cu dispozițiile Codului penal, așa cum ar fi modificate, dacă, cu o zi înainte, persoana ar întreține

\footnotetext{
${ }^{13}$ Disponibil la: http://www.cdep.ro/proiecte/2020/100/00/1/cl131.pdf

${ }^{14}$ Vezi Proiect disponibil la: http://www.cdep.ro/proiecte/2020/100/00/1/se131.pdf
} 
un act sexual, partenerul ar risca să intre la pușcărie pentru 10 ani. Comentariile sunt, și aici, de prisos...

Al doilea proiect de lege, „cireașa de pe tortul epidemiei”, este PL-x nr. 216/29.04.2020 - Proiect de Lege pentru modificarea şi completarea art. 218 din Legea nr. 286/2009 privind Codul penal ${ }^{15}$ (în continuare „Proiectilul”). Deși propunerea legislativă este dezarmant de simplă, ea are o putere de ,penetrare electorală” bine calculată (de aici și denumirea propusă de mine - „Proiectilul”). Astfel, litera c) de la alin. (3) al art. 218 C.pen. ( victima este un minor) se abrogă, iar după alin. (6) se introduce un nou alineat (7) cu următorul cuprins: „, Pedeapsa este detențiunea pe viață atunci când victima este un minor". Scurt și cuprinzător cum s-ar spune și, mai ales, penetrant în masa amorfă a acelei părţi ,,amorţite” a electoratului. „Proiectilul” vine cu un mesaj clar: noi suntem cei care îi trimit la „pușcărie pe viață” pe cei care vă violează copiii. Este posibil să nu ne votați?

În mod înţelept, Consiliul Legislativ a avizat negativ propunerea şi a explicat, în mod elegant, că aceasta încalcă principiul fundamental al individualizării pedepsei, precum și principiul adaptabilității sancțiunilor de drept penal. Se mai atrage atenția că ,pedeapsa detențiunii pe viață este prevăzută (fără alternativă - n.n.) numai în cazul variantei agravate constând în săvârșirea în timp de război a uneia dintre infracțiunile contra păcii și omenirii, respectiv infracțiunea de genocid - art. 438 alin. (2) din Codul penal"16.

$\mathrm{Nu}$ pot fi la fel de elegant precum Consiliul Legislativ și voi spune de-a dreptul că „Proiectilul” este o ,gogomănie juridică” fără egal. În fața unei astfel de aberații legislative ar fi chiar jenant să aduc argumente juridice legate de logica și ierarhia pedepselor, de principiul fundamental al individualizării pedepsei mai sus amintit, etc. Am să le aduc doar la cunoștință propunătorilor acestui „Proiectil” că în Codul penal, la art. 189, există infracțiunea de omor calificat care prevede pedeapsa cu detențiunea pe viață sau închisoarea de la 15 la 25 de ani. Printre împrejurările care califică omorul pot fi amintite: fapta săvârșită cu premeditare (lit. a), asupra a două sau mai multor persoane (lit. f) și prin cruzimi (lit. h). În traducere, ca să fiu înțeles și de propunători, dacă făptuitorul, cu premeditare (adică după ce chibzuiește și pregătește fapta) ucide mai multe persoane (să presupunem zece persoane, toate minore) prin cruzimi (adică le supune la suferințe deosebite şi prelungite) are prin lege (cel puţin teoretic) alternativa pedepsei cu închisoarea de la 15 la 25 de ani, pe lângă cea a detențiunii pe viață. Ca să știţi!

Ceea ce mi se pare de-a dreptul revoltător, în acest caz, este faptul că această aberație legislativă a fost adoptată de Senat ca urmare a depășirii termenului de adoptare, potrivitart.75alin.(2) teza a III-a din Constituția României republicata ${ }^{17}$. Adică, așa cum ar spune "gurile rele", a fost adoptată prin „procedura indolenței parlamentare”. Trist dar adevărat. Este inutil să mai calific

\footnotetext{
${ }^{15}$ A se vedea: $h$ ttp://www.cdep.ro/pls/proiecte/upl pck2015. proiect?cam=2\&idp=18259

${ }^{16}$ Disponibil la: http://www.cdep.ro/proiecte/2020/200/10/6/cl265.pdf

${ }^{17}$ A se vedea: http://www.cdep.ro/pls/proiecte/upl pck2015. proiect?cam=2\&idp=18259
} 
împrejurarea că această propunere ignoră total primul Proiect amintit mai sus, votat în unanimitate în același Senat!?! Deși este evident că cele două Proiecte se exclud reciproc, totuși, ele au fost promovate de același for legislativ. Că tot vorbeam mai sus despre legiferarea ,pe colțul mesei”...

Ca să fiu bine înțeles: agresiunile sexuale de orice fel asupra minorilor și mai ales violurile reprezintă fapte extrem de grave care trebuie să fie ferm sancționate, cu pedepse severe. Codul penal prevede aceste pedepse, ele trebuie doar să fie aplicate, ținând cont de particularitățile fiecărei fapte. Mărirea pedepselor este, în sine, o măsură iluzorie și, oricum, limitată. În orice caz, nu propunerile legislative populiste îi vor pune pe minori la adăpost de astfel de fapte. Dacă autorităţile sunt în mod real îngrijorate și preocupate de fenomenul reprezentat de agresiunile sexuale asupra minorilor, ar trebui să elaboreze și să pună în practică strategii preventive inteligente. Să ne reamintim în acest context vechiul principiu conform căruia este mai important să previi decât să pedepsești.

În concluzie, pe baza datelor oferite de ,anamneza epidemiologică” la care se adaugă constatările rezultate din verificarea „stării patologice actuale”, ipoteza de la care am plecat se confirmă: virusul 3 P s-a reactivat și el amenință, din nou, sănătatea justiției penale. Ar trebui să lucrăm la un vaccin...

$14 / 06 / 20$

Materialul a fost publicat în revista online a Facultăţii de Drept, $\underline{\text { AUBD-Forum }}$ Juridic nr. 2/2020. 